\title{
Epidemiologic Study on Hepatitis A Virus Seroprevalence in Busan
}

\author{
Kyung-Soon Cho and So-hyun Park \\ Division of Epidemiology, Busan Institute of Health and Environment, Busan 616-842, Korea
}

\begin{abstract}
The prevalence of hepatitis A virus (HAV) in a certain community reflects that community's living standard and hygienic condition. The seroprevalence rate of IgG anti-HAV has been changing with regions and times. In this study, we aimed to study the difference of seroprevalence of IgG anti-HAV according to sex, age and type of drinking water, and to know the vaccination rate and seroconversion rate for vaccinated subjects in Busan. A total of 644 samples were analyzed. The overall seroprevalence rate of IgG anti-HAV was 35.4\% (228/644). There was no significant difference in sex (male 39.8\%, female 32.7) ( $p>0.05)$. According to age, seroprevalence rate of anti-HAV were $55.0 \%$ in subjects aged $5 \sim 9$ years old, $47.8 \%$ in $10 \sim 14$ years old, decreced to $10.6 \%$ in $15 \sim 19$ years old, $1.0 \%$ in $20 \sim 24$ years old, $0.0 \%$ in $25 \sim 29$ years old and increced with advacing ages; $14.7 \%$ in $30 \sim 34$ years old, $39.4 \%$ in $35 \sim 39$ years old, $67.3 \%$ in $40 \sim 44$ years old, $94.1 \%$ in $45 \sim 49$ years old, $100.0 \%$ over 50 years ( $p<0.001)$. The seroprevalence of IgG anti-HAV was no statistical difference according to the types of drinking water $(p>0.05)$. The vaccinated subject was 42 case only in below 25 years old. The seroconversion rate after vaccination was $88.1 \%$.
\end{abstract}

Keywords: Drinking water, Hepatitis A virus (HAV), Seroprevalence, Seroconversion rate, Vaccination rate

This is an Open Access article distributed under the terms of the Creative Commons Attribution Non-Commercial License (http://creativecommons.org/licenses/by-nc/3.0) which permits unrestricted non-commercial use, distribution, and reproduction in any medium, provided the original work is properly cited.

Copyright @ 2014 The Korean Society for Clinical Laboratory Science. All rights reserved.
Corresponding author: Kyung-Soon Cho Division of Virus, Busan institute of health and Environment, Busan 616-842, Korea Tel: 82-51-309-2810

E-mail: viruscho@korea.kr

Received: February 8, 2014 Revised: March 28, 2014

Accepted: March 28, 2014

\section{서 론}

A형 간염 바이러스(hepatitis A virus, HAV)는 1973년 Feinstone 등이 사람의 분변에서 처음 발견하여 $\mathrm{A}$ 형 간염의 병인을 정립하였 다. $\mathrm{A}$ 형 간염은 경제수준 및 공중위생과 밀접한 관련이 있고, 대변구강 경로로 감염되는 감염성이 매우 높은 질환이다. 위생상태가 나쁘고, 경제수준이 낮은 지역에서 분변에 오염된 음식물이나 식수 를 섭취하여 간접적인 경로로 전파되거나 사람 간의 접촉을 통해 직접적인 경로로 전파되기도 한다(Roh 등, 1997).

우리나라도 경제수준이 낮았던 과거 1980년대 초 보고에 의하 면 취학으로 인한 공동생활이 시작되는 10 세 이전에 A형 간염 항체 양성률이 급격하게 상승하고, 20세 이전에 대부분이 A형 간염 바이 러스에 노출되어서 항체를 획득하였다. 6 세 이하에서는 HAV에 감 염되어도 $70 \%$ 이상이 무증상이므로 과거에는 A형 간염이 큰 문제 가 되지 않았다(Hadler 등, 1980).
그러나 지난 30년간 고도의 경제성장을 이루면서 공중위생 및 생활환경의 개선으로 소아 연령의 $\mathrm{A}$ 형 간염 바이러스에 대한 노출 이 줄어들면서 청소년 및 젊은 성인층에서의 $\mathrm{A}$ 형간염 항체율이 급 속히 감소하여 학교나 군대 등의 단체생활과 외식 증가로 인해 $\mathrm{A}$ 형 간염에 접할 가능성이 높아졌다. $\mathrm{A}$ 형 간염의 임상양상이 성인에서 는 대부분이 심한 증상을 보이는 현증 간염의 형태를 보인다. 40 세 이상 연령 또는 만성 C형간염, 알콜성 간염 등의 만성 간질환을 동 반한 환자의 경우 전격성 간염이나 사망에 이르는 경우가 증가한다 고 알려져 있다(Keeffe, 1995; Vento 등, 1998).

역학적으로 과거 1980년대 국내 A형 간염 항체 양성률은 1세 이 후에 증가하기 시작하여 10 세가 되면 50\%정도를 보이고 10 19 세 $86.4 \%, 20$ 세 이후에는 대부분이 항체를 가지고 있었으나(Hong 와 Kim, 1982; Kim와 Lee, 1982) 1990년대 중반에는 20세 이하 의 항체 양성률이 9 15\%로 감소하였고(Jung 등, 1995; Roh 등, 1997), 1990년대 말에는 21 25세에서 54\%로 항체 양성률이 20 
세 이상에서도 감소함을 보고하였다(Choi 등, 1999). 또한, 2000 년 중반에 서울과 경기에서 시행된 항체 양성률 보고에서는 20세 이하는 11 18\%, 20 24세 20 23\%, 25 30세 40 42\%로 전 반적인 항체 양성률의 감소가 높은 연령대로 옮겨감을 보여주었다. 이러한 혈청학적 조사 결과를 통해 국내 $\mathrm{A}$ 형 간염 감수성 집단 분포 가 선진국 양상과 유사하고, 소아와 젊은 성인에서 현증 A형간염의 발생 위험이 커졌다는 것을 알 수 있다. 실제로 1996년 대전시 서북 부에서 식수원의 오염으로 추정되는 A형 간염의 폭발적 발생이 있 었으며(Choi 등, 1997), 1996년 1월부터 2005년 3월까지 광주 · 전남지역에도 산발적인 발생이 보고되었다(Jung, 2005).

최근 현증 A형 간염 환자 발생이 증가하고 있고, 환자의 $80 \%$ 가 가정과 사회의 주된 활동연령층인 20 39세로, 이들이 상당 기간 업무에 종사하지 못함으로 인한 사회 - 경제적 손실이 클 것으로 예 상된다(Jung와 Kim, 2009). 이러한 상황은 성인에서 개인위생관 리 및 생활환경을 개선시키는 방법을 통해 A형 간염을 예방하고 고 위험 집단을 대상으로 적극적인 예방접종을 시행할 필요성이 있으 며, 소아에서도 A형 간염 예방접종을 통해 집단감염의 전파 경로를 차단하여 무증상 소아환자와의 접촉으로 인해 이차적으로 성인에 서 A형 간염이 발생하는 것을 줄일 필요성이 있음을 보여준다.

$\mathrm{A}$ 형 간염 유병율은 생활환경과 위생상태에 밀접한 관계가 있으 며, 연대별 및 연령에 따라 다양한 양상을 보인다. 최근 서울, 대전, 광주 등 타 지역에서는 A형 간염 항체 보유률에 대한 보고가 있었다 (Jung 등, 1995; Jung, 2005; Jung 등, 2011; Yun 등, 2011). 그러 나 부산지역의 경우 병원에 내원한 소아 및 성인에 대한 연구 (Kwon, 2007)는 있으나 최근 부산지역에 거주하는 다양한 연령대 의 A형 간염 항체 보유율에 대한 보고는 없는 실정이다.

이에 본 연구에서는 2012년 4월부터 11월까지 부산지역에 거주 하는 다양한 연령대를 대상으로 연령별, 성별, 음용수 섭취 방법별 로 A형 간염 바이러스 항체 보유율을 조사하고, 예방 접종을 받은 연령대를 대상으로 연령별 예방접종률과 항체 생성률도 조사하여 $\mathrm{A}$ 형 간염의 역학적 특성을 이해할 뿐 아니라 A형 간염에 대한 예방 및 관리에 필요한 정보를 제공하고자 한다.

\section{재료 및 방법}

\section{1. 연구대상}

2012년 4월부터 2012년 11월까지 부산지역 대학교 3곳(D대 학, P대학, S대학), 연구원 1곳, 제약회사 1곳, 사회복지시설 1곳, 초등학생 소년소녀합창단 1 곳, 중·고등학생 견학 및 체험교실 1 곳, 관내 보건소 방문자 중 부산지역 건강인 지원자 총 644 명을 대 상으로 혈청을 채취하여 $\mathrm{IgG}$ anti-HAV 검사를 시행하였다. 모든 대상군은 본인 및 부모로부터 검체 채취 동의서를 받았다. 검체 채 취 동의서에는 성별, 나이, 거주지, 예방접종 여부, 음용수 섭취방 법에 대한 설문 조사도 실시하였다.

\section{2. 방법}

대상자로부터 혈액 $3 \mathrm{~mL}$ 을 채취하여 혈청분리관에 $4^{\circ} \mathrm{C}$ 에서 $3,000 \mathrm{rpm}$ (한일 원심분리기, $\mathrm{HM}-160$ )으로 15 분간 원심분리시 킨 후 혈청을 분리하여 의료용면역형광측정장치(mini VIDAS, BioMerieux, Italia sp)로 VIDAS Anti-HAV Total (BioMeieux, France)시약을 사용하여 A형 간염 항체 유무를 면역형광법 (Enzyme Linked Fluorescent Assay)으로 측정하였다.

\section{3. 자료분석과 통계}

검체 채취 동의서에 기록된 설문 내용(나이, 성별, 거주지, 예방 접종 여부, 예방접종유무, 음용수 섭취 방법)과 $\mathrm{A}$ 형 간염 항체 유무 를 자료로 연령별, 성별, 음용수 섭취 방법에 따른 항체 보유율, 예 방접종자에 대한 연령별 예방접종률 및 항체 생성률은 Chi-square 검정을 시행하여 차이가 있는지 분석하였고 $p$ 값이 0.05 미만일 때 통계적으로 유의하다고 판정하였다.

\section{결과 및 고찰}

\section{IgG anti-HAV 보유율}

총 644 명이 연구 대상에 포함되었으며 이중 남자가 246명 (38.2\%), 여자가 398명(61.8\%)이었다. 연령별은 5 9세 40명 (6.1\%), 10 14세 46명(6.1\%), 15 19세 65명(10.2\%), 20 24세 101명(15.7\%), 25 29세 90명(14.0\%), 30 34세 75명(11.6\%), 35 39세 66명(10.2\%), 40 44세 55명(8.5\%), 45 49세 51명

Table 1. Subjects Distribution according to sex and age

\begin{tabular}{lccccccccccc}
\hline Age (yr) & $5 \sim 9$ & $10 \sim 14$ & $15 \sim 19$ & $20 \sim 24$ & $25 \sim 29$ & $30 \sim 34$ & $35 \sim 39$ & $40 \sim 44$ & $45 \sim 49$ & $50 \leq$ & Total (\%) \\
\hline Male & 17 & 12 & 23 & 27 & 42 & 25 & 25 & 23 & 30 & 21 & $246(38.2)$ \\
Female & 23 & 34 & 42 & 74 & 48 & 50 & 41 & 32 & 21 & 33 & $398(61.8)$ \\
Total (\%) & $40(6.1)$ & $46(7.1)$ & $65(10.2)$ & $101(15.7)$ & $90(14.0)$ & $75(11.6)$ & $66(10.2)$ & $55(8.5)$ & $51(7.9)$ & $54(8.4)$ & 644 \\
\hline
\end{tabular}




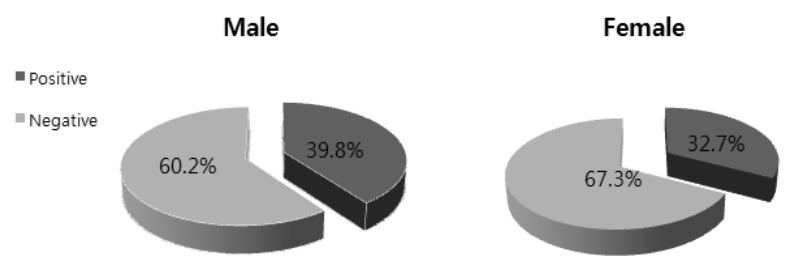

Fig. 1. The seroprevalence of IgG anti-HAV according to sex. There was no statistical difference $(p<0.05)$.

(7.9\%), 50세 이상을 54명(8.4\%) 대상으로 하였다(Table 1).

\section{1) 성별에 따른 IgG Anti-HAV 보유율}

전체 대상군의 IgG Anti-HAV 보유율 35.4\% (228/644)이었다. 성별에 따른 $\operatorname{IgG}$ Anti-HAV 보유율은 남자가 39.8\% (98/246), 여 자가 $32.7 \%$ (138/398)로 남자가 다소 높았지만 통계학적인 유의 한 차이는 없었다 $(p>0.05)$ (Fig. 1).

$\mathrm{A}$ 형 간염의 성별 발생 빈도에 대한 연구에서 남자가 여자보다 유 병률이 높다는 보고(Lee 등, 2011)가 있으나 성별에 따른 IgG Anti-HAV 보유율은 이전의 국내 여러 보고(Lee 등, 2011; Song 등, 2007; Yun 등, 2011)에서도 통계학적인 차이는 보이지 않았다.

\section{2) 연령에 따른 IgG Anti-HAV 보유율}

연령에 따른 $\operatorname{IgG}$ Anti-HAV 보유율은 큰 차이를 보였다 $(p$ <0.001) (Fig. 2). 특히 25 29세 항체 보유율은 0.0\% (0/101)로 가장 낮았고, 20 24세 1.0\% (1/90)로 확인되었으나 이는 예방접 종에 의한 항체 생성으로 보여졌다. 다음으로 15 19세 $10.6 \%$ (7/66), 30 34세 14.7\% (11/75), 35 39세 39.4\% (26/66), 10 14세가 47.8\% (22/46), 5 9세 55.0\% (22/40), 40 44세 67.3\% (37/55), 45 49세 94.1\%(48/51), 50세 이상 100\% (54/54) 순이 었다. 15 세 미만에서는 예방접종의 영향으로 $51.2 \% \operatorname{IgG~Anti-HAV~}$ 보유율을 보이다가 15 19세에서 급속히 감소하였으며 20대는 거 의 존재하지 않았기에 D대학과 S대학에 학생들 대상으로 혈청을 채취하여 추가 검사를 통해 IgG Anti-HAV 보유율이 매우 낮았음 을 재확인하였다. 30 대부터 다시 증가하기 시작하여 40 대 이후 급 속히 증가하는 경향을 보였다.

이전 2004 2005년 부산지역 병원에 내원한 소아 및 성인을 대 상으로 한 $\operatorname{IgG}$ Anti-HAV 보유율 조사에서는 2 5세 1.7\%, 6 10 세 $1.7 \%, 11 \sim 20$ 세 $0 \%, 21$ 30세 $40.5 \%, 31 \sim 40$ 세 $82.1 \%, 41$ 50 세 94.7\%, 51세 이상 100\%로 보고되었고(Kwon 등, 2007) 본 연구와 비슷한 시기 전국을 대상으로 한 조사에서는 $\operatorname{IgG}$ Anti-HAV 보유율이 5 9세 69.8\%, 10 14세 38.8\%, 15 19세 13.0\%, 20 29세 11.7\%, 30 39세 52.2\%, 40 49세 83.2\%, 50 세 이상 89.3\%로 확인되었다(Lee 등, 2011). 본 연구 결과에서 15

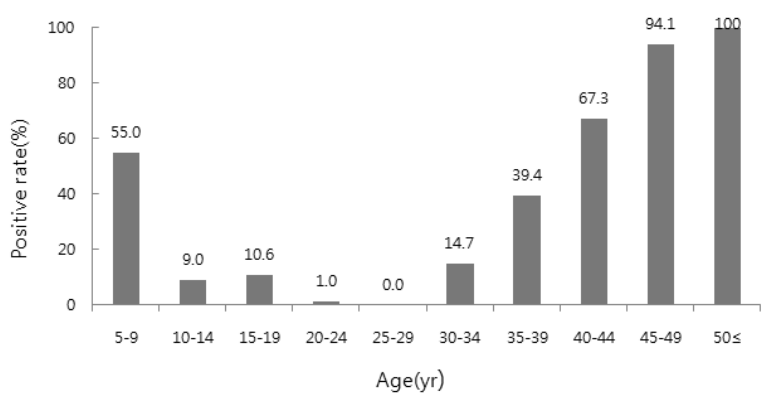

Fig. 2. The seroprevalence of IgG anti-HAV according to age. There was statistical difference $(p<0.001)$.

세 미만 연령에서는 지난 7 8년에 비해 증가하였지만 전국 IgG Anti-HAV 보유율에 비해 낮은 경향으로 보였다. 이는 1996년 A형 간염 산발적 집단 발생 후 2000 년 초 이후 $\mathrm{A}$ 형 간염 백신 접종의 홍 보 결과로 지난 과거에 비해 시민들이 $\mathrm{A}$ 형 간염 및 위생관리의 관심 도가 증가하였으나아직 A형 간염 유병률이 타 지역에 비해 낮은 부 산 지역의 경우 전국에 비해 경각심이 낮은 것으로 사료된다(Choi 등, 1999; Choi 등, 1997). 또한 15 39세 연령에서는 과거 부산지 역 및 비슷한 시기 전국 IgG Anti-HAV 보유율에 비해 낮게 나타났 다(Choi 등, 1999; Choi 등, 1997). 이는 경제성장 및 도시 정화로 인한 환경위생 상태의 향상으로 소아의 자연 항체 획득 기회 감소 의 결과로 사료된다. 특히 부산지역 일반인과 두 곳의 대학교 학생 20대의 경우 IgG Anti-HAV 보유율은 거의 존재하지 않았음이 확 인되었고, 최근 A형 간염 유병률의 $80 \%$ 가 가정과 사회의 주된 활동 연령층인 20 30대 젊은 성인으로 이들이 상당 기간 업무에 종사 하지 못함으로 인한 사회 - 경제적 손실이 우려되므로, 이들 고위험 연령대에 대한 구체적인 예방대책이 필요할 것이라 생각한다.

\section{2. 대상자들의 음용수 섭취방법에 따른 IgG Anti-HAV 보유 분포}

대상자들의 음용수 섭취 방법에 따른 IgG Anti-HAV 보유 분포 는상수도 물 가열 섭취한 경우 112 건(41.5\%)으로 가장 높았고, 정 수기 물 또는 생수를 그대로 섭취 70건(28.6\%), 정수기 물 또는 생 수를 가열 섭취 29건(38.2\%), 상수도 물 그대로 섭취 9건(36.0\%) 순으로 확인되었으며, 그 외 지하수 가열섭취, 약수터 물 가열섭취, 지하수 그대로 섭취, 약수터 물 그대로 섭취는 각 5건 이하로 보였 다(Fig. 3). 음용수 섭취 방법과 IgG Anti-HAV 보유는 통계학적인 유의관계가 보이지 않았다 $(p>0.05, \mathrm{n}>10)$.

$\mathrm{A}$ 형 간염의 오염원으로는 어패류, 식수, $\mathrm{A}$ 형 간염 환자와의 접 촉, 유행지역 장기간 여행 등이며 국가 및 지역에 따라차이가 있었 다(Pickering 등, 2006). 북미 및 북유럽은 유행지역 여행자, 서유 럽은 약물 중독, 이탈리아는 어패류와 식수가 가장 큰 위험인자이 며, 대만에서는 분변에 의한 지하수 오염이 가장 큰 원인이었다 


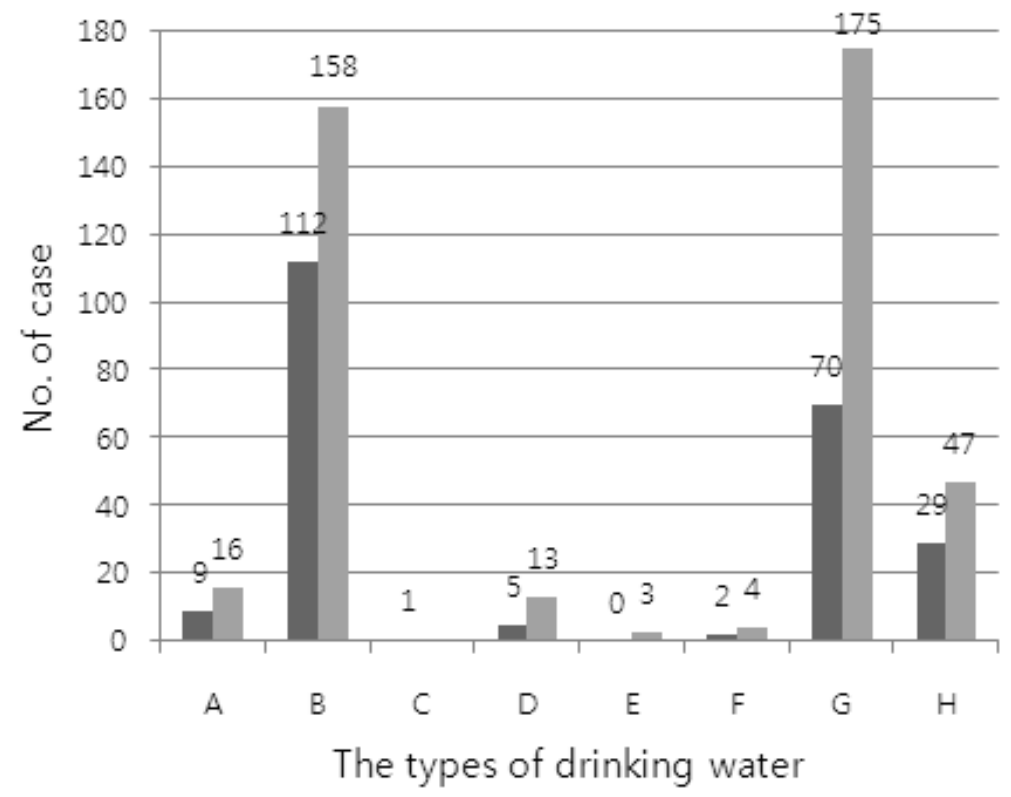

$$
\begin{aligned}
& \text { No. of Anti-HAV } \\
& \text { IgG Positives } \\
& \text { No. of Anti-HAV } \\
& \text { IgG Negatives }
\end{aligned}
$$

A : Tap Water/Dringking water

B: Tap Water/Drinking the boiled Water

$C$ : Ground water/Dringking water

$D$ : Ground water/Drinking the boiled Water

E: Spring Water/Dringking water

$F$ : Spring Water/Drinking the boiled Water

$G$ : Bottlered water and Filtered tap water /Dringking water

$\mathrm{H}$ : Bottlered water and Filtered tap water /Drinking the boiled Water

Fig. 3. Samples distribution according to the types of drinking water. There was no statistical difference $(p>0.05)$.

Table 2. The Vaccination rate and Seroconversion rate of IgG anti-HAV according to Age

\begin{tabular}{crc}
\hline Age $(y r)$ & Vaccination rate $(\%)$ & Seroconversion rate $(\%)$ \\
\hline $5 \sim 9$ & $20 / 40(50.0)$ & $18 / 20(90.0)$ \\
$10 \sim 14$ & $18 / 46(39.1)$ & $15 / 18(83.3)$ \\
$15 \sim 19$ & $3 / 65(4.6)$ & $3 / 3(100.0)$ \\
$20 \sim 24$ & $1 / 101(1.0)$ & $1 / 1(100.0)$ \\
\hline
\end{tabular}

(Cromeans 등, 1994). 우리나라 경우도 1996년 대전에서 식수원 오염에 의한 $\mathrm{A}$ 형 간염의 집단발생이 있었다. 여기서 IgG Anti-HAV 미보유자가 오염된 식수원 등 감염원에 노출시 현증 감염이 발생할 수 있다는 보고가 있다(Keeffe, 1995; Kim, 2008; Yang 등, 1999).

따라서 본 연구에서는 A형 간염 발생의 원인인자 중 음용수 섭취 방법에 따른 IgG Anti-HAV 보유율을 조사하였으나 상관관계가 없 음을 확인하였다. 그러나 여러 보고에서 밝혀진 바와 같이 $\mathrm{A}$ 형 간염 집단 발병 예방을 위해 음용수의 위생 관리를 더욱 철저히 해야된 다고 사료된다.

\section{3. 예방접종률 및 항체생성률}

전체 대상군 중 예방접종자는 25 세 미만에서 42 건 보였다. 연령 대별로는 5 9세에서 20건(50.0\%)으로 가장 높았고, 다음으로 10 14세 18건(39.1\%), 15 19세 3건(4.6\%), 20 24세 1건(1.0\%) 순으로 보였다. 예방접종 후 항체 생성률은 $88.1 \%$ (42건 중 37건) 이었다(Table 2). 2009년 대전 충남 지역에서 10세 미만을 대상으 로 한 보고에 따르면 예방 접종률은 $50.6 \%$ 이며(Feinstone 등,
1973), 예방접종 후 항체 생성률은 1 차 접종 후 $85 \%$ 보였으며 본 연 구에서 10 세 미만과 비교할 때 유사한 양상을 보였다.

$\mathrm{A}$ 형 간염은 잠복기가 평균 28 일로 증상 발현 2주 전부터 바이러 스 농도가 높게 나타나고, 이때가 감염력이 가장 높은 시기이다. 그 러나 소아에서는 불현성 간염으로 나타나는 경우가 많아 A형 간염 유행시 원인 파악이 어려운 점이 있다(Cromeans 등, 1994; Pickering 등, 2006). 또한 성인에서는 증상이 현저한 현증 급성 간 염의 형태로 주로 발병하게 되고(Kim, 2008), 젊은 성인층에서 항 체보유율이 급격히 감소하여 이로 인해 현증 A형 간염이 크게 늘어 날 가능성이 있다. 그런데 아직까지 $\mathrm{A}$ 형 간염은 직접적인 치료약제 가 없고 침상안정, 적절한 영양공급 등의 보존적 치료를 위주로 하 므로 예방을 하는 것이 중요하다. 공중보건학적 측면에서 식수원 오염배제, 적절한 분뇨처리 그리고 손씻기 같은 개인위생 철저 등 공중위생의 확립에 의한 일반적인 예방도 중요하지만 동남아 등 타 국가로의 여행객 증가, 외국인 노동인력 유입, 남북간 인적 왕래 증 가 등의 위험 요인이 커져감을 고려해 볼 때 A형 간염 예방백신 접 종을 통한 적극적인 예방 사업으로 항체보유율을 증가시켜 집단 면 역을 형성하는 것이 필요하다고 사료된다. 현재 우리나라에서는 A 형 간염 항체가 없는 소아나 고위험군 성인(A형 간염 풍토병 지역 에서 거주하거나 여행하는 경우, 남성 동성연애자, 약물중독자, 혈 액 응고 질환, 직업상 위험인자 연구사에 종사하는 사람, 만성간질 환자)에게 국가 필수예방접종이 아닌 비용효과측면을 고려한 선택 접종을 하는 실정이다.

본 연구를 통해 부산 지역 IgG Anti-HAV 보유율은 다른 연령층 
에 비해 15 39세에서 낮았으며, 이 연령층은 지난 7 8년 전보다 감소하였으며 2009 2010년 타 시도보다 낮았음이 확인되었다. 특히 20대 연령층에서 A형 간염 항체가 거의 나타나지 않았으므로 $\mathrm{D}$ 대학과 $\mathrm{S}$ 대학에 학생들 대상으로 혈청을 채취하여 추가 검사를 통해 IgG Anti-HAV 보유율이 매우 낮았음을 재확인하였다. 최근 급성 $\mathrm{A}$ 형 간염이 발생하는 주 연령층이 20 30대이라는 점과 이 연령층이 학교, 군대 등 단체 생활 및 사회 활동이 왕성하다는 것을 고려할 때 $\mathrm{A}$ 형 간염에 노출 되었을 때 대규모로 일어날 가능성이 높 다. 또한 질병관리본부 감염병 웹 통계(http://stat.cdc.go.kr)에 따 르면 부산지역은 타 지역에 비해 $\mathrm{A}$ 형 간염 발생 수는 적으나 B형 및 $\mathrm{C}$ 형 간염 환자 발생 수가 많으므로, 이들 만성 간질환 환자에게 $\mathrm{A}$ 형 간염 중복 감염시 중증질환으로 이환될 가능성도 높다(Jung 등, 2011). 따라서 이들 고위험군 연령층에 대한 A형 간염에 대한 적극 적인 홍보와 아울러 건강 검진시 $\mathrm{A}$ 형 간염 항체 유무 검사를 필수 항목으로 지정하여 항체 미보유자 대해 catch-up 접종을 하는 것 이 비용면에서도 효과적일 것이라 생각된다. 또한 사회 경제적 수 준과 공중위생 수준이 향상되면서 과거와는 달리 20세 전에 A형 간 염의 자연면역 획득이 어려우므로 10세 이전에 적극적인 예방접종 을 통해 집단 감염의 전파 경로를 차단하여 이차 감염을 줄일 수 있 다고 사료된다.

\section{참고문헌}

Choi W, Eom H. S., Kim I. H., Lee D. H., Kim P .S., Kim H. G., et al. Patterns of acute hepatitis A and anti-HAV seropreva lence of Kyungin province. Korean J Gastroenterol, 1999, 34;69-75.

Choi J. W., Lee K. I., Lee D. Z., Han J. H., Hang S. S., Lee K. S. Outbreak of hepatitis A in Taejon in 1996; clinical and epidemiologic study in children. Korean J Int Med, 1997, 4:90-96.

Cromeans T, Nainan O. V., Fields H. A., Favorov M. O., Margolis H. S., Foodborne diease-Handbook Hepatitis A and E viruses 1994, pp.1-56. 2nd. Culinary and Hospitality Industry Publication Services.

Feinstone S. M., Kapikian A. Z., Purceli R. H., Hapatitis A: detection by immune electron microscopy of a viruslike antigen associated with acute illness. Science. 1973, 182;1026-1028.

Hadler S. C., Webster H. M., Erben J. J., Swanson J. E., Maynard J. E., Hepatitis A in day-care centers. A community-wide assessment. $N$ Engl J Med, 1980:302, pp.1222-1227.

Hong W. S., Kim J. R. A seroepidemiologic study of hepatitis A and B infection in Seoul. Korean J Int Med 1982:25, pp.19-26.

Jung G. M., Yeon J. E., Bak Y. T., Kim J. H., Kwon S. Y., Byun K. S., et al. Epidemiologic study of hepatitis A viral infection in Seoul [Abstract]. Korean J Gastroenterol, 1995, 27, (Suppl2), A117.

Jung P. J., Kim D. H., Joo I. K., Park C. H., Lee W. S., Joo Y. E., et al. Clinical characteristics of sporadic hepatitis A in GwangjuJeonnam province. Korea J Hepatol, 2005, 11, ;65.

Jung Y. K., Kim J. H., Epidemiology and clinical features of acute hepatitis A: from the domestic perspective. Korean J Hepatol. 2009, $15 ; 438-445$

Jung J., Ahn Y. J. and Moon K. R., An Epidemiologic Study on the Seropositive Rate of Hepatitis A Virus in Children of Gwangju and Jeonnam. Korean J Pediatr Gastroenterol Nutr, 2011, 14(1):67- 73.

Keeffe E. B. Is hepatitis A more severe in patients with chronic hepatitis B and other chronic liver diseases, Am J Gastroenterol, 1995, 90:.201-205.

Kim T. W., Lee K. J. Antibody to hepatitis A antigen inchildren and adolescents in Korea. J Korean Pediatr Soc, 1982, 25:36-40.

Kim J. H. Recent Epidemiological Status and Vaccination of Hepatitis A in Korea. J Korean Med, 2008, 51(2), :110-118.

Kwon Y. O., Choi I. J., Jung J. W. and Park J. H., An epidemiologic study on the seropositive rate of hepatitis A virus among a selected group of children and adults in Busan. Korean J Pediatrics, 2007, 50(3):262-267.

Lee H. J., Cho H. K., Kim J. H. and Kim K. H. Seroepidemiology of Hepatitis A in Korea : Change over the Past 30 Years. J Korean Med. Sci, 2011, 26:791-796.

Pickering L. K., Baker C. J., Long S. S. American Academy of Pediaterics : Hepatitis A, 2006 Report of the Committee on infectious Diseases, McMillian JA, 2006, 27:326-335.

Roh H. O., Sohn Y. M., Park M. S., Choi B. Y., Bang K. N., Ki M. R., et al. A seroepidemiologic study of hepatitis A virus in healthy children and adolescent in Kyonggi-do province. Korean J Pediatr Infect Dis, 1997, 4:232-239.

Song Y. B., Lee J. H., Choi M. S., Koh K. C., Paik S. W., Yoo B. C., et al. The Age-specific Seroprevalence of Hepatitis A Virus Antibody in Korea. Korean J Hepatol, 2007, 13(1):27-33.

Vento S, Garofano T, Renzini C, Cainelli F, Casali F, Ghironzi G, et al. Fulminant hepatitis associated with hepatitis A virus superinfection in patients with chronic hepatitis C. NEngl JMed, 1998, 338:286-290.

Yang D. W., Lee Y. A., Shim J. Y., Park J. Y., Jung H. L., Park M. S. et al. A Seroepidemiologic Study on Hepatitis A in Seoul, Korea. J. Korean Pediatr Soc, 1999, 42(2):180-185.

Yun S. W., Lee W. K., Cho S. Y., Moon S. H., Shin H. D., Yun S. Y., et al. The Seroprevalence Rate, Vaccination Rate and Seroconversion Rate of Hepatitis A in Central Region of Korea. Korean $J$ Gastroenerol, 2011, 57(3):166-172.

Yun H. S., Lee H. J., Cheon D. S., Chu C. S., Oh K. W., kim Y. T., et al. Seroprevalence of Hepatitis A and E virus based on the third korea national health and Nutrition survey in korea. Public Health Res Perspect, 2011, 2(1). :46-50. 